P-ISSN: 2774-4574; E-ISSN: $2774-4582$

TRILOGI, 2(1), Januari-April 2021 (61-70) @2021 Lembaga Penerbitan, Penelitian, dan Pengabdian kepada Masyarakat (LP3M) Universitas Nurul Jadid Paiton Probolinggo

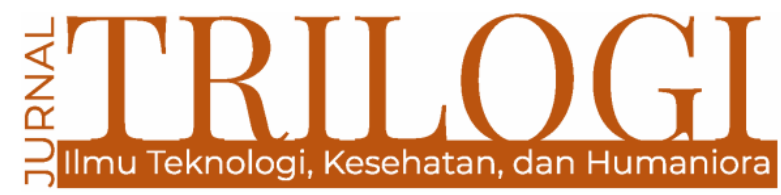

\title{
PENINGKATAN KEMAMPUAN MEMBACA AL-QUR'AN MELALUI SCIENTIFIC APPROACH PADA PEMBELAJARAN ILMU TAJWID DI SD INSAN TERPADU SUMBERANYAR PAITON PROBOLINGGO
}

\author{
Musolli \\ Universitas Nurul Jadid, Probolinggo \\ musolli@unuja.ac.id

\section{Makrufah} \\ Universitas Nurul Jadid, Probolinggo \\ makrufa.imron@gmail.com
}

\begin{abstract}
This study discusses learning tajwid in improving the ability to read the Qur'an through a scientific approach at SD Insan Terpadu Sumberanyar Paiton. Learning tajwid is part of the procedure for reading the Qur'an, so that in its journey many methods or approaches are found in learning. One approach that can be used to strengthen the learning of tajwid is scientific learning, namely a learning approach which consists of activities; observing, questioning, associating, experimenting, and networking. This study uses a qualitative case study type method. The results of his research show that the Scientific Approach approach in the learning process of Tajweed Science at SD Insan Terpadu is very effective so that it can improve students' reading of the Qur'an and is very enjoyable. In addition, students are also able to master the material of recitation, gharib, and hadiths that they have learned.
\end{abstract}

Keywords: keyword 1; keyword 2; keyword 3

\begin{abstract}
Abstrak
Penelitian ini membahas tentang pembelajaran ilmu tajwid dalam meningkatkan kemampuan membaca Al-Qur'an melalui scientific approach di SD Insan Terpadu Sumberanyar Paiton. Pembelajaran ilmu tajwid adalah sebagai bagian dari tata cara membaca Al-Qur'an, sehingga dalam perjalanannya banyak ditemukan metode atau pendekatan dalam pembelajarannya. Salah satu pendekatan yang dapat digunakan untuk penguatan pembelajaran ilmu tajwid adalah scientific learning, yaitu pendekatan pembelajaran yang di dalamnya terdiri dari aktivitas; observing, questioning, associating, exprimenting, and networking. Penelitian ini menggunakan metode kualitatif jenis studi kasus. Hasil penelitiannya menunjukkan bahwa pendekatan Scientific Approach dalam proses pembelajaran Ilmu Tajwid di SD Insan Terpadu berjalan sangat efektif sehingga mampu meningkatkan bacaan al-Qur'an para siswa dan sangat menyenangkan. Selain itu, santri juga mampu menguasai materi tajwid, gharib, dan hadits-hadits yang sudah di pelajarinya.
\end{abstract}

Katakunci: Pembelajaran Ilmu Tajwid, Scientific Approach 


\section{Pendahuluan}

Pendidikan termasuk hal yang penting dalam kehidupan manusia, dengan pendidikan, manusia dapat belajar semua ilmu pengetahuan. karena pada dasarnya manusia dalam melaksanakan kehidupan sehari-hari tidak lepas dari pendidikan. Pendidikan dalam pandangan yang sebenarnya adalah suatu sistem pendidikan yang memungkinkan seseorang dapat mengarahkan kehidupannyasesuai dengan cita-cita Islam, sehingga dengan mudah ia dapat membentuk hidupnya sesuai dengan ajaran Islam (Umar, 2010). Pendidikan sebagai jalan satu-satunya menuju kehidupan yang sangat tentram dan damai baik didunia juga di akhirat. Bagaimana manusia akan tentram didunia apabila ia tidak mengetahui ilmu-ilmu dunia? Begitu juga untuk memperoleh kedamaian di akhirat harus mengetahui jalan menuju kedamaian akhirat. Untuk mengetahui kedua jalan tersebut harus menggunakan kendaraan ilmu, berupa pendidikan (Razak, 2011).

Pendidikan sangat penting dalam kehidupan manusia, baik pendidikan formal maupun non formal, karena melalui pendidikan seseorang bisa membedakan anatara mana yang baik dan mana yang buruk. Dalam proses pendidikan Islam terdapat usaha mempengaruhi jiwa anak melalui proses, setingkat demi setingkat, menuju tujuan yang ditetapkan, yaitu menanamkantakwadan akhlak serta menegakkan kebenaran sehingga terbentuklah manusia yang berkepribadian dan berbudi luhur sesuai dengan ajaran Islam (Arifin, 1991). Begitu pentingnya ilmu pengetahuan bagi manusia sehingga dapat menjadikan seseorang lebih tinggi derajatnya jika dibandingkan dengan orang lain yang tidak berilmu pengetahuan. Karena keberhasilan proses pendidikan disuatu lembaga tidak terlepas dari kegiatan proses belajar disekolah. Salah satu faktor yang mempengaruhi keberhasilan pendidikan didalamnya terdapat strategi guru yang menciptakan ruang kelas menjadi aktif, misalnya dengan menggunakan metode atau pendekatan tertentu dalam pembelajaran, karena dengan menggunakan metode atau pendekatan dalam pembelajaran peserta didik lebih aktif dan lebih antusias dalam melaksanakan pembelajaran yang aktif dan menyenangkan.

Roy Kellen berpendapat bahwa terdapat dua pendekatan dalam pembelajaran, yaitu pendekatan yang berpusat pada guru (teachercentered approaches) dan pendekatan yang berpusat pada siswa (student-centered approaches). Pendekatan yang berpusat pada guru menurunkan strategi pembelajaran langsung 62 (direc intruction), pembelajaran deduktif atau pembelajaran ekspositori. Sedangkan, pembelajaran yang berpusat pada siswa menurunkan strategi pembelajaran inkuiri dan discoveri serta pembelajaran induktif (Rusman, 2013).

Mengingat pentingnya peran Al-Qur'an bagi kehidupan manusia, makapengenalan Al-Qur'an mutlak diperlukan. Upaya mengenalkan Al-Qur'an itu bukanhanya mengetahui dari segi fisik dan aspek sejarah semata, namun yang lebihpenting adalah bagaimana umat Islam mampu membaca sekaligusmemahami maknayang terkandung dalam butir-butir ayat demi ayat dari Al-Qur'an (Zulfison \& Muharram, 2003). Namun, dalam realitas kehidupan masyarakat sehari-hari dijumpai masih banyak yang belum mampu membaca Al-Qur'an dengan baik dan benar. Jangankan untuk memahami atau menghayati AlQur'an dengan baik, membacanya pun terkadang bagi sebagian besar umat Islam masih mengalami kesulitan.Sebagai suatu cabang ilmu, sebagian besar muslim tentunya telah mengenalilmu tajwid sebagai bagian dari tata cara membaca Al-Qur'an, sehingga dalamperjalanannya banyak ditemukan metode atau pendekatan dalam pembelajaran ilmu tajwid. Dengan pembelajaran yang aktif dan menyenangkan maka siswa sangat antusias untuk mengikuti pembelajaran ilmu tajwid.

Pembelajaran ilmu tajwid sangat membutuhkan metode atau pendekatan. Metode atau pendekatan merupakan faktor yang paling penting dalam proses belajar mengajar. Metode yang digunakan dalam pembelajaran Al-Qur'an sering kali tidak relevan walaupun sebenarnaya dalam suatu lembaga itu sudah ada ketentuan dalam menggunakan metode pembelajaran ilmu tajwid tetapi kebanyakan dari pihak pendidik masih belum menerapkan metode tersebut.

Seorang pendidik yang tidak dapat menyesuaikan metode mengajar dan tidak dapat menguasai teknik mengajar dan ia berusaha dengan jalan tidak wajar, pengajaran semacam ini sangat menyedihkan murid sehingga timbul kurangnya disiplin, rendahnya mutu pembelajaran dan tidak ada perhatian serta kesungguhan dalam belajar (Surachmad, 1980).

Dalam perancangan kurikulum 2013, pendekatan yang digunakan dalam pembelajaran yaitu pendekatan ilmiah (ScientificApproach). Pendekatan ini lebih efektif hasilnya jika diimplementasikan di dalam kelas, yaitu meningkatnya kemampuan siswa dari aspek pengetahuan (kognitif), sikap (afektif), dan keterampilan (psikomotor) (Baharun, 2017). Pendekatan ilmiah atau scientific approach pada 
pelaksanaan pembelajaran menjadi bahan pembahasan yang sangat menarik perhatian bagi para pendidik akhir-akhir ini, terutama setelah diberlakukannya kurikulum 2013. Yang menjadi latar belakang pentingnya materi ini karena produk pendidikan dasar dan menengah belum menghasilkan lulusan yang mampu berpikir kritis setara dengan kemampuan anak-anak bangsa (Musfiqon, 2015).

Penerapan pendekatan saintifik (ilmiah) dalam pembelajaran di sekolah bertujuan untuk membiasakan peserta didik berfikir, bersikap, serta berkarya dengan menggunakan kaidah dan langkah ilmiah. Proses pembelajaran menjadi lebih penting dibandingkan hasil pembelajaran. Peserta mengalami lebih bermakna dibandingkan peserta didik memahami (Musfiqon, 2015). Pendekatan ilmiah (sciantific approach) sangatlah dibutuhkan dalam proses pembelajaran, supaya proses pembelajaran dalam kelas berlangsung secara aktif, efisien dan tidak monoton.

Scientific approach berkaitan erat dengan metode saintific. Para ahli meyakini bahwa scientific approach dapat menjadikan siswa lebih aktif dalam membangun pengetahuan dan keterampilannya serta dapat mendorong siswa melakukan penyelidikan guna menemukan faktafakta dari suatu fenomena. Proses pembelajaran yang mengimplementasikan scientific approach akan menyentuh tiga ranah, yaitu: sikap, pengetahuan, dan keterampilan (Sani, 2014).

Pembelajaran dengan mengimplementasikan pendekatan ilmiah akan lebih aktif dan terampil, dibandingkan dengan pembelajaran yang menggunakan metode ceramah atau metode tradisional, karena dapat membuat peserta didik menjadi bosan dan kehilangan perhatiannya, serta menjadikan peserta didik pendengar yang pasif. Pembelajaran yang menggunakan pendekatan saintifik akan mendorong siswa lebih aktif dan lebih menyenangkan dalam pembelajaran di kelas.

Pelaksanaan pembelajaran Al-Qur'an dapat dilakukan dengan beberapametode atau pendekatan yang menyenangkan. Dengan pembelajaran yang aktif dan menyenangkan maka peserta didik sangat antusias untuk mengikuti pembelajaran Al-Qur'an. Sekolah SD Insan Terpadu adalah salah satu lembaga yangmenitikberatkan pada pembelajaran Al Qur'an.Berdasarkan observasi singkat di SD Insan Terpadu pembelajaran Al-qur'an ilmu tajwidnya menggunakan scientific approach. Dengan menggunakan metode atau pendekatan ilmiah yang aktif dan menyenangkan peserta didik lebih antusias, cepat fasih dan lancar dalam pembelajaran ilmu tajwid.

Sekolah dasar SD Insan Terpadu Sumberanyar Paiton Probolinggo Full Day school mengupayakan siswanya agar bisa membaca Al-Qur'an dengan baik dan benar, Sistem pembelajaran Al-Qur'an di SD Insan Terpadu dibagi menjadi tiga kelas, yaitu kelas dasar, kelas Al-Qur'an dan kelas finishing. Kelas dasar merupakan kelas yang pertama kali harus di tempuh oleh santri sebelum memasuki kelas Al-Qur'an, setelah santri sudah memasuki kelas Al-Qur'an, santri memasuki kelas finishing yakni membaca Al-Qur'an dengan memahami ilmu Tajwid dan Gharib.

Proses pembelajaran Al-Qur'an di SD Insan Terpadu tercipta keadaan yang sangat kondusif, sehingga peserta didik sangat antusias dalam pembelajaran Al-Qur'an. Kegiatan pembelajaran al-Qur'an dilaksanakan di kelas-kelas, untuk peserta didik yang sudah mencapai pembelajaran Tajwid dilaksanakan di masjid. Berdasarkan dari hal tersebut, menjadi hal yang menarik untuk diteliti di Sekolah SD Insan Terpaduini sebagai lokasi penelitian dalam rangka mengkaji pendekatan Saintific Approacch yang diterapkan dalampembelajaran ilmu tajwid demi meningkatkan kemampuan membaca Al-Qur'an yangbaik dan benar sesuai dengan kaidah Tajwid.

\section{Metode}

Penelitian ini merupakan penelitian kualitatif jenis studi kasus, dengan menggunakan pendekatan pedagogis. Pendekatan pedagogis yakni pendekatan yang dilakukan dengan menggunakan teori-teori pendidikan dalam proses pembelajaran untuk mencapai keberhasilan pelaksanaan pembelajaran utamanya menguraikan proses pembelajaran yang lebih menekankan makna dari pada generalisasi. Instrumen yang digunakan dalam penelitian ini adalah pedoman wawancara yang berisi daftar pertanyaan, pedoman observasi, dan beberapa dokumentasi yang berkaitan dengan objek penelitian. Teknik pengumpulan data yang dilakukan dalam penelitian ini adalah Observasi, Wawancara, Dokumentasi. Sedangkan Untuk melaksanakan analisis data kualitatif ini maka perlu ditekankan beberapa tahapan dan langkahlangkah, yakni: Reduksi data, Penyajian data, penarikan kesimpulan.

Penelitian yang dilakukan di SD Insan Terpadu, Sekolah Dasar Insan Terpadu merupakan SD Unggulan swasta di daerah Paiton Probolinggo, berdiri pada tahun 2003. SD Insan Terpadu 
merupakan sekolah di bawah naungan Yayasan Nahdhotul Ummah dengan dewan pengasuh $\mathrm{KH}$. Ach. Fauzi Imron. Lc. M. Sc.

\section{Hasil dan Pembahasan}

\section{Penerapan Scientific Approach pada Pembelajaran IImu Tajwid di SD Insan Terpadu Sumberanyar Paiton}

Secara umum penerapan merupakan sebuah tindakan yang berupa tindakan menerapkan suatu kejadian, hal, atau peristiwa. Maksud dari penerapan ini adalah berupa menerapkan pembelajaran Ilmu Tajwid yang di gunakan ustadz atau ustadzah untuk mendampingi peserta didik dalam belajar membaca Al-Qur'an dengan baik dan benar sesuai kaidah-kaidah IImu Tajwid di SD Insan Terpadu Sumberanyar Paiton.

SD IT merupakan sekolah dasar full day school yang mengupayakan siswanya agar bisa membaca al-qur'an dengan baik dan benar. Sd IT merupakan sekolah yang berdiri di bawah naungan pondok pesantren Nahdhatul Ummah dan sudah terakreditasi $A$.

Sekolah Dasar SD IT dalam perkembangannya menjadi sekolah kebanggaan dan menjadi salah satu sekolah unggulan di Paiton, ini tidak lepas dari program yang dikembangkan sekolah. Setiap lembaga pendidikan memiliki ciri khas atau program unggulan, demikian juga dengan SD IT. Di Sekolah Dasar Insan Terpadu Sumberanyar Paiton yang jadi program unggulan adalah program Al-Quran, baik dari segi tilawah, Tajwid dan Ghorib, hafalan surat-surat pendek, dan hafalan doa-doa sehari-hari.

Penerapan pembelajaran Al-Qur'an di SD Insan Terpadu ini merupakan hasil mufakat seluruh guru dalam membantu dan meningkatkan kemampuan membaca Al-Qur'an siswa di SD Insan Terpadu. Penerapan pembelajarannya dilakukan di pagi hari sejak pukul 07.30 - 08.30 untuk kelas 1 dan 2, dan pada pukul 11.15 - 13.00 untuk kelas 3 sampai kelas 6. Sesuai dengan kelompok dan kemampuan peserta didik, para ustadz dan ustadzah juga berpencar sesuai dengan kelompok guna mendampingi peserta didik dalam belajar membaca Al-Qur'an sesuai metode yang di terapkan di sekolah.

Penerapan pembelajaran Ilmu Tajwid di SD Insan Terpadu dalam pembelajaran membaca AlQur'an merupakan komponen yang sangat penting dalam mengembangkan lembaga ini menuju perkembangan yang lebih baik, karena masa anak-anak adalah masa awal perkembangan kepribadian manusia, apabila kita mengajarkan yang baik maka akan memperoleh hasil yang baik. Begitu juga mengajarkan Al-Qur'an pada pasa anak-anak maka akan lebih di serap oleh mereka.

penerapan pembelajaran Ilmu Tajwid ini menekankan pada Scientific Approach (pendekatan ilmiah) yaitu dengan mengamati yang meliputi melihat, mendengar dan membaca, setelah itu anak di kasih kesempatan tanya jawab, jika anak sudah faham apa yang sudah di pelajarinya maka anak di suruh mengkomunikasikannya misal dalam pembelajaran Tajwid anak di suruh mengurai IImu Tajwid pada bacaan yang sudah dibaca.

Scientific Approach adalah pendekatan yang digunakan dalam pembelajaran yang dilakukan melalui proses ilmiah. Dalam proses ilmiah siswa mengkonstruk pengetahuan dengan menanya, melakukan pengamatan, melakukan pengukuran, mengumpulkan data, mengorganisir dan menafsirkan data, memperkirakan hasil, melakukan eksperimen, menyimpulkan dan mengkomunikasikan. Scientific Approach adalah pendekatan penbelajaran yang dilakukan melalui proses mengamati (observing), menanya (quistioning), mencoba (experimenting), menalar (associating) dan mengkomunikasikannya (communication).

Kurikulum 2013 menggunakan pendekatan scientific karena pendekatan ini dinilai sesuai untuk mengembangkan sikap, pengetahuan, dan keterampilan siswa. Pembelajaran dengan pendekatan scientific adalah proses pembelajaran yang dirancang sedemikian rupa agar siswa secara aktif mengkonstruk konsep, hukum atau prinsip melalui tahapan-tahapan mengamati (untuk mengidentifikasikan atau menemukan masalah), merumuskan masalah, mengajukan atau merumuskan hipotesis,mengumpulkan data dengan berbagai teknik, menganalisis data, menarik kesimpulan, dan mengkomunikasikan konsep, hukum atau prinsip yang "ditemukan".

Pendekatan scientific yang dimaksudkan untuk memberikan pemahaman kepada siswa dalam mengenal, memahami berbagai materi menggunakan pendekatan scientific. Pembelajaran diarahkan untuk mendorong siswa mencari tahu dari berbagai sumber melalui pengamatan, bukan sekedar di berikan oleh guru. Tujuan dari pendekatan ini adalah siswa mampu memecahkan masalah yang akan dihadapi di kehidupan sehari-hari dengan baik.

Langkah - langkah pendekatan scientific dalam proses pembelajaran adalah mengamati, menanya, mengumpulkan informasi atau 
mencoba, menalar atau mengasosiasi, mengkomunikasikan.

Pendekatan ilmiah atau scientific aprroach pada pelaksanaan pembelajaran menjadi bahan pembahasan yang menarik perhatian para pendidik akhir-akhir ini, terutama setelah diberlakukannya kurikulum 2013. Yang menjadi latar belakang pentingnya materi ini karena produk pendidikan dasar dan menengah belum menghasilkan lulusan yang mampu berpikir kritis setara dengan kemampuan anak-anak bangsa lain.

Penerapan pembelajaran IImu Tajwid di SD Insan Terpadu menekankan pada pendekatan ilmiah (Sientific Approach). Berikut adalah langkah-langkah pembelajaran Ilmu Tajwid di SD Insan Terpadu :

1. Opening (pembukaan) yaitu dalam pelaksanaan pembelajaran Al-Qur'an di SD Insan Terpadu sebelum santri memulai membaca Al-Qur'an semua santri di anjurkan membaca doa-doa. Dengan harapan semoga semua santri diberi kemudahan dalam belajar Al-Qur'an.

2. Sebelum santri memulai membaca AlQur'an santri dianjurkan Untuk berwudlu, semua santri harus mempunyai wudlu sebelum memulai belajar Al-Qur'an.

3. Observing (mengamati) yaitu dengan mengamati yang meliputi melihat, mendengar dan membaca. Sebelum memulai pembelajaran Ilmu Tajwid semua santri membaca Al-Qur'an bersama (Tadarus), setelah tadarus ustadz menjelaskan satu pokok pembahasan materi Tajwid misal menjelaskan tentang hukum nun sukun atau tanwin ada lima.

4. Quistioning (menanya) setelah santri memahami tentang materi yang sudah di jelaskan oleh ustadz santri di kasih kesempatan tanya jawab tentang apa yang sudah di pelajarinya. Kompetensi yang diharapkan dalam kegiatan ini adalah mengembangkan kreativitas, rasa ingin tahu, serta melihat perkembangan santri kira-kira sudah faham atau belum apa yang sudah mereka pelajarinya.

5. Associating (menalar), di SDInsan Terpadu tidak hanya pembelajaran Tajwid saja yang di pelajarinya, santri juga dianjurkan hafalan doa-doa harian, doa-doa shalat dan hadits -hadits tentang kewajiban menuntut ilmu, keutamaan belajar Al-Qur'an, membaguskan bacaan Al-Qur'an dan lain sebagainya, kompetensi yang diharapkan di samping santri bisa membaca Al-Qur'an dengan baik dan benar santri juga bisa memahami tentang pentingnya mempelajari IImu Tajwid.

6. Networning (mengkomunikasikan), jika anak sudah faham dengan apa yang sudah di pelajarinya maka anak di suruh mengkomunikasikan misal dalam pembelajaran Tajwid anak di suruh praktek mengurai Tajwid pada bacaan yang sudah dibaca, misal santri di suruh baca satu ayat dalam satu ayat itu kira-kira ada berapa bacaan tajwid.

7. Closing (penutupan), setelah selesai dalam pembelajaran Al-Qur'an di tutup dengan bacaan doa bersama-sama.

Temuan peneliti berdasarkan teori tentang pembelajaran ilmu tajwid melalui scientific approach di SD IT berjalan sangat efektif dan sistematis karena dengan adanya penerapan scientific approach pada pembelajaran ilmu tajwid menunjukkan bahwa anak-anak sudah benarbenar fasih dan lancar dalam membaca Al-Qur'an.

Data tersebut didukung oleh hasil dokumentasi metodologi pembelajaran kelas jilid dan kelas AlQur'an di SD Insan Terpadu yaitu:

1. Kelas Al-Qur'an Juz 27/Juz 30

a. 15 menit pertama: membaca besama (tadarus)

b. 30 menit: individu

c. 15 menit: membaca besama

2. Kelas Juz 1-10

a. 15 menit pertama: membaca besama (tadarus)

b. 30 menit: individu

c. 15 menit: membaca besama

3. Kelas Juz 11-20 + Ghorib

a. 15 menit pertama: Membaca besama

b. 15 menit kedua: Dril mim kecilQowariro / Liman -Lil 'Aalimina

c. 10 menit: penjelasan satu pokok bahasan (kondisional)

d. 20 menit: setoran hafalan

4. Kelas Juz 21-30 + Tajwid
a. 15 menit pertama: Membaca besama dan ayat terakhir diurai
b. 15 menit kedua: Drill buku tajwid
c. 10 menit: penjelasan satu pokok bahasan (kondisional) dan praktek mengurai kalimat
d. 20 menit: setoran hafalan

5. Materi Hadits, Doa Harian, Surat-surat pendek, Bacaan Wudu' dan sholat serta praktek dilaksanakan pada hari khusus

6. Kelas Finishing
a. Metode I 
1) 30 menit: Membaca besama dan ayat terakhir diurai

2) 30 menit: Pendalaman materi tajwid, Ghorib, Doa-doa, hadits, surat pendek, bacaan wudu' dan praktek/bacaan sholat dan praktek

b. Metode II

1) 15 menit: Membaca besama dan ayat terakhir diurai

2) 45 menit:

a) Pendalaman materi surat pendek dari Ad-Dhuha - Al-Qori'ah + tajwid + hadits

b) Pendalaman materi surat pendek dari At-Takatsur - Annas + Ghorib + Doa Harian.

Di sekolah dasar Insan Terpadu tidak hanya pembelajaran tajwid dan ghorib saja yang di tekankan tetapi juga siswa juga dianjurkan untuk menghafalkan surat-surat pendek, bacaan wudlu dan praktek shalat, hadist- hadist pilihan diantaranya adalah hadist keutamaan belajar AlQur'an, membaguskan bacaan Al-Qur'an, kewajiban menuntut ilmu, akhlak dan lain sebagainya.

Dari sinilah siswa bisa menalar keterkaian pembelajaran ilmu tajwid dengan hadist-hadist pilihan tentang keutamaan belajar Al-Qur'an yang sesuai dengan kaidah-kaidah ilmu tajwid. Dari definisi para ahli di atas, dapat disimpulkan bahwa pendekatan ilmiah adalah proses pembelajaran yang mendorong anak untuk melakukan kegiatan ilmiah dengan mengamati, menanya, mengumpulkan informasi/eksperimen, menalar, dan mengomunikasikan. siswa mampu mengkomunikasikkan hasil pembelajaran ilmu Tajwid dan gharib dengan cara mengurai tajwid pada bacaan Al-Qur'an yang sudah dibaca.

Berhasilnya suatu proses pembelajaran sangat ditentukan beberapa faktor, diantaranya adalah faktor pendekatan belajar khususnya dalam belajar Al-Qur'an. Tanpa metode atau pendekatan, suatu materi pelajaran tidak akan dapat berproses secara efisien dan efektif dalam kegiatan pembelajaran menuju tujuan pendidikan. Oleh karena itu, keberhasilan proses pembelajaran sangat ditentukan oleh Metode atau pendekatan, maka setiap guru sebagai pengajar atau pendidik harus mengetahui berbagai metode atau pendekatan mengajar dan dapat menguasai penerapan setiap metode, sebab metode mengajar baru akan berfungsi dengan baik bilamana guru mampu menguasai dan memilih secara tepat di dalam penerapannya.

\section{Peningkatan Kemampuan Membaca Al- Qur'an melalui Scientific Approach di SD Insan Terpadu Sumberanyar Paiton}

Kemampuan membaca Al-Quran hendaknya dimiliki anak sejak dini. Kemampuan membaca AlQuran merupakan bekal kehidupan anak. Kegiatan pembelajaran membaca Al-Qur'an harus memperhatikan kaidah syar'i. Kemampuan membaca Al-Qur'an adalah kecakapan membaca Al-Qur'an dengan bagus dan benar sesuai dengan tuntunan syari'at sebagaimana yang dijelaskan pada ilmu tajwid.

Mengembangkan kemampuan membaca AlQuran yang baik dan benar memerlukan tahapantahapan tertentu, hal ini sesuai dengan teori yang mengungkapkan bahwa kemampuan membaca Al-Quran dapat dimiliki melalui beberapa tahapan, yaitu tahap kemampuan melafadkan huruf-huruf dengan baik dan benar, sesuai dengan makhroj dan sifatnya. Kemampuan membaca Al-Quran dapat diraih melalui tiga tahapan, yaitu mengenal karakteristik huruf, bunyi huruf, dan membacanya.

Membaca Al-Qur'an sesungguhnya boleh dikatakan sesuatu hal yang sangat mudah, tetapi yang lebih sulit adalah bagaimana mengajarkan kemudian diaplikasikan oleh siswa yang diajar, sehingga nantinya siswa yang diajar akan menghasilkan kualitas bacaan yang sesuai dengan kaidah-kaidah Al-Qur'an.

Nabi Muhammad pernah bersabda bahwa (AlNaisaburi, t.th):

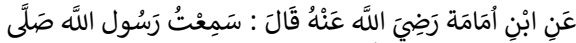

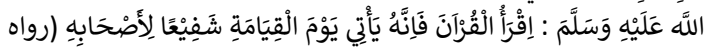

$$
\begin{aligned}
& \text { مسلم) }
\end{aligned}
$$

Artinya: "Abu Umamah r.a. berkata: Saya mendengar sabda Rasulullah demikian:Bacalah Al-Qur'an sebab di hari kiamat nanti bisa memberi syafaat kepada pembacanya."

Keterangan hadis di atas, menggambarkan adanya suatu motivasi yang dapat menginspirasi seseorang untuk belajar dan membaca Al-Qur'an. Kata syafa'at pada hadis di atas adalah suatu hal yang juga dinanti-nantikan oleh setiap manusia di hari kemudian nanti, terutama bagi mereka yang mendapatkan siksa akibat perbuatannya ketika hidupnya di dunia ini. Mereka inilah, menantikan datangnya syafa'at. Namun, karena ketiadaan mereka membaca Al-Qur'an, sehingga syafaat pun tak kunjung datang.

Hadis tersebut menuntut agar orang-orang Islam sedapat mungkin menghayati dan mengamalkan Al-Qur'an, minimal mereka dapat membacanya secara fasih. Untuk itulah, 
seseorang dituntut agar dapat belajar dan mempelajari Al-Qur'an paling tidak dapat membacanya, apalagi mampu membaca, mengkaji, menelaah, memahami dan menghayati lalu kemudian mengamalkannya dalam setiap perilaku dan setiap ucapan. Demikian keutamaan belajar dan mengajarkan Al-Qur'an, sehingga nabi pun pernah bersabda bahwa membaca saja AlQur'an itu mendapat pahala dan juga jika diajarkan kepada orang lain. Hal ini telah disabdakan oleh Rasulullah saw.

Sebagaimana diriwayatkan dari Ibnu Mas'ud sebagai berikut (An-Nawawi, 1972):

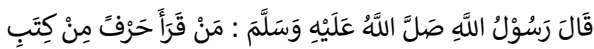

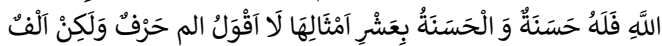

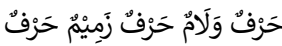
(رواه الترمزى) ( )

Artinya: Rasulullah saw. bersabda: "Barangsiapa membaca satu huruf Al-Qur'an maka dia mendapat satu pahala. Pahala ini dilipat gandakan lagi sepuluh kali. Saya (Muhammad) tidak berkata alif lam mim itu satu huruf, tetapi alif dihitung satu huruf, lam satu huruf, dan mim satu huruf."

Hadis di atas menunjukkan bahwa membaca Al-Qur'an satu huruf saja akan mendapat pahala yang berlipat ganda. Jadi keutamaan orang yang belajar dan mengajarkan Al-Qur'an itu selain pahala yang diperoleh akan mendapatkan tempat yang baik di sisi Allah pada hari kiamat, sebab AlQur'an akan menjadi syafa'at baginya.

Kemampuan membaca Al-Qur'an dapat meningkat apabila ada kemauan untuk belajar efektif dan kreatif disamping dengan adanya guru yang mampu membimbingnya. Di SD Insan Terpadu merupakan sekolah yang sangat modern yang selalu mengupayakan siswanya untuk membiasakan berprikehidupan Islami agar menjadi umat yang berakhlak mulia, cinta pada Allah SWT, bakti kepada orang tua dan selalu menjadikan Al-Qur'an dan As-Sunnah sebagai rujukan seluruh aktifitas kehidupan.

Pada proses pembelajaran Al-Qur'an di SD IT menerapan scientific approach dapat mengaktifkan siswa karena dengan menggunakan pendekatan ini siswa dapat meningkatkan kemampuan membaca Al-Qur'an dengan aktif dan menyenangkan. Untuk dapat meningkatkan kemampuan membaca al-qur'an dengan baik dan benar bukan suatu pekerjaan yang mudah. Semua pekerjaan atau program akan berjalan lancar dan berhasil dalam mencapai target yang telah ditetapkan, jika menggunakan suatu metode atau pendekatan yang tepat. Keberhasilan dalam mencapai tujuan yang telah ditentukan juga tergantung kepada pemilihan dan penerapan suatu metode atau pendekatan, sistem atau cara yang tepat. Dan semua akan berjalan secara efektif dan efisien.

Dalam pembelajaran Ilmu Tajwid di SD IT Sumberanyar Paiton menggunakan Pendekatan ilmiah (scientific approach) dalam pembelajaran sebagaimana dimaksud meliputi Observing (pengamatan), Questioning (bertanya), Associating (menalar), Exprimenting (mencoba), Networking (mengkomunikasikan). Proses pembelajaran Al-Qur'an melalui pendekatan ilmiah ini harus menyentuh ketiga ranah, yaitu sikap, pengetahuan, dan keterampilan.

Setiap peserta didik yang belajar Al-Qur'an dengan memahami kaidah-kaidah ilmu tajwid dan gharib, tentunya menginginkan waktu yang cepat dan singkat, serta tidak gampang lupa apa yang sudah dipelajarinya, hal tersebut dapat terlaksana apabila peserta didik yang belajar Al-Qur'an menggunakan metode yang tepat, rajin, dan istiqamah dalam menjalani prosesnya, walaupun cepatnya belajar seseorang tidak terlepas dari otak atau IQ yang dimiliki.

Kegiatan pembelajaran IImu Tajwid guru membuka secara luas dan bervariasi kesempatan peserta didik untuk melakukan pengamatan melalui kegiatan; membaca, melihat, menyimak, dan mendengar. Guru memfasilitasi peserta didik untuk melakukan pengamatan, melatih mereka untuk melihat, membaca, mendengar buku tajwid yang di pegang oleh santri. Kemudian guru memberi kesempatan untuk bertanya pada peserta didik untuk mengembangkan rasa ingin tahu peserta didik. Semakin terlatih dalam bertanya maka rasa ingin tahu semakin dapat dikembangkan.

Data tersebut didukung oleh hasil dokumentasi dengan adanya dokumen waktu pelaksanaan pembelajaran tajwid dan gharib di SD Insan Terpadu. Dapat di lihat pada gambar sebagai berikut :

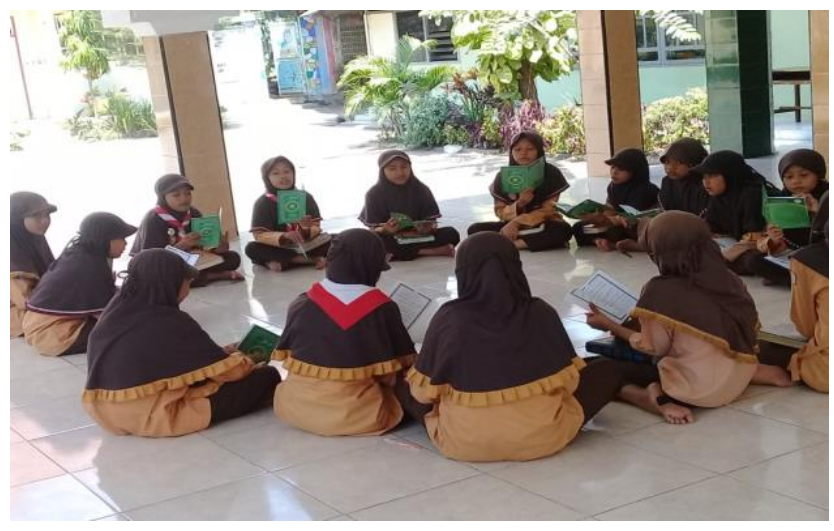


Dalam pembelajaran Al-Qur'an ustadz yang mengajar Al-Qur'an selalu memberi pertanyaan pada santri. Setelah santri baca Al-Qur'an bersama-sama santri di kasih pertanyaan oleh ustad, misal bacaan yang sudah di baca di tanya tentang tajwid atau gharib. Dalam belajar AlQur'an tidak bisa serta-merta dengan otodidak, walaupun dengan tingkat kecerdasan yang tinggi, karena dalam membaca Al-Qur'an menuntut adanya praktik langsung di hadapan ustadz sehingga ustadz dapat menuntun santri/murid kepada bacaan yang fashih dan shahih (benar). Berkembangnya dan keinginan untuk bertanya, sangat dipengaruhi oleh suasana pembelajaran yang dikembangkan oleh seorang guru.

Pelaksanaan pembelajaran IImu Tajwid dengan menggunakan Sientific Approach di SD Insan Terpadu telah berjalan dengan efektif dan sistematis, hal ini di dukung dengan adanya pembinaan guru-guru yang diadakan di lembaga setiap satu minggu sekali dan di cabang Kraksaan dalam satu bulan sekali. Semua guru yang mengajar Al-Qur'an diwajibkan mengikuti pembinaan SMQ (silaturrahim muallimin Qur'an) tiap satu bulan sekali pada hari minggu di cabang kraksaan dan SMQ di lembaga diadakan tiap satu minggu sekali pada hari sabtu, untuk menambah pengalaman dan pengetahuan setiap guru yang mengajar Al-Qur'an di SD Insan Terpadu.

Setiap guru yang mengajar Al-Qur'an harus benar-benar mampu dalam menyampaikan materi yang harus di ajarkan karena akan menjadikan seseorang lebih mudah dalam menerima materi yang telah disampaikan. Setelah para ustadz ustadazah mengikuti pembinaan dan memperoleh materi-materi yang berkaitan dengan pembelajaran Al-Qur'an maka ustadz atau ustadzah dinyatakan mampu dalam mengajar mengajar Al-Qur'an. Dengan adanya para ustadz dan ustadzah yang mampu dibidangnya maka tujuan pembelajaran akan berjalan dengan efektif dan sistematis. Di SD Insan Terpadu para ustadz dan ustadzahnya bisa dinyatakan mampu karena mengikuti pembelajaran dan pembinaan yang di adakan oleh JQH (Jam'iyah Ahlul Qura Wal Huffadz).
Data tersebut didukung oleh hasil dokumentasi dengan adanya dokumen waktu pelaksanaan SMQ (silaturrahim mu'allimin Qur'an) di SD Insan Terpadu. Dapat di lihat pada gambar sebagai berikut :

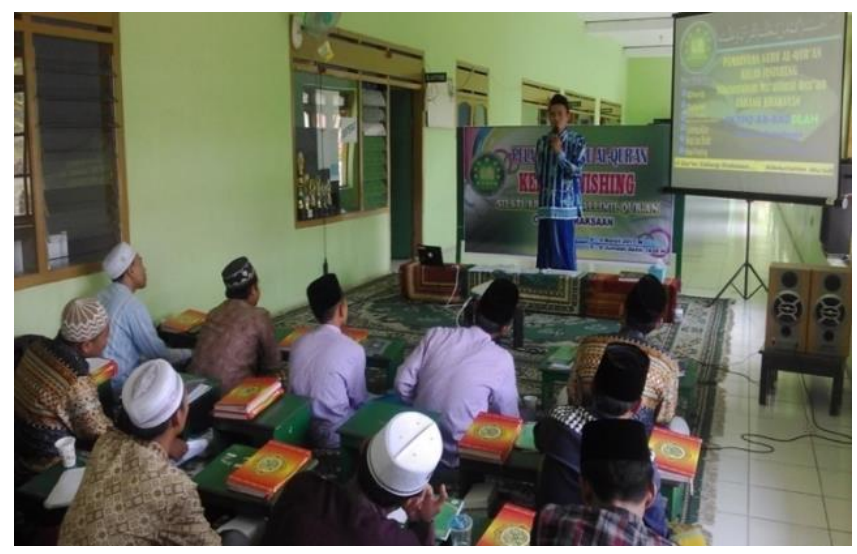

Acara SMQ para ustadz ustadzah yang di adakan di cabang kraksaan, untuk menambah pengetahuan dan pengalaman tentang pembelajaran Al-Qur'an di adakan setiap satu bulan sekali, berpindah-pindah tempat antar satu lembaga ke lembaga yang lain.

Proses pembelajaran Al-Qur'an sangat kondusif, anak-anak sangat antusias dalam mengikuti pembelajaran Al-Qur'an yang bukti nyatanya anak-anak banyak menjuarai lombalomba tartil yang diikutinya. Dan pembelajaran AlQur'an ini sangat berpengaruh juga pada pembelajaran PAI, anak-anak mudah dalam menghafalkan surat-surat pendek dengan menerapkan makhorijul huruf dan ilmu tajwid.

Dalam pembelajaran Al-Qur'an SD Insan Terpadu sering mengikutkan lomba-lomba Tartil yang di adakan di kota Probolinggo, SD Insan Terpadu sering menjuarai dalam lomba-lomba tartil yang di ikutinya, adapun juara yang pernah di raih adalah Juara Tartil tingkat Kecamatan acara HUT tahun 2016 , Lomba Tahfid di Kabupaten juara 1 Aaki arif kelas 6, untuk tingkat Kecamatan juara 2 kls 5, Lomba Tahfid acara HUT Kota Kraksaan juara 1 putri Zidna Amalia kls 5 dan juara 2 Zaki Arif, juara 3 Tahfid pentas pais yg mengadakan Kemenag, Tashih secabang Kraksaan santri terbaik 1 dan 3 untuk tingkat anak2 sekitar 177 peserta.

Kemampuan dalam meningkatkan membaca Al-Qur'an melalui Sientific Approach dalam proses pembelajaran Ilmu Tajwid di SD Insan Terpadu berjalan sangat efektif dan menyenangkan karena dengan adanya pendekatan ilmiah bisa menunjukkan bahwa anak-anak itu sudah benarbenar fasih dan lancar dalam membaca Al-Qur'an. 
Pernyataan diatas bisa dibuktikan dengan adanya tiap tahun SD Insan Terpadu mampu melaksanakan wisuda anak-anak yang hatam AlQur'an binnadhor dan Tahfidz juz 30. Adapun sebelum di wisuda anak-anak harus melalui evaluasi atau tes yang sudah ditentukan oleh sekolah, Santri yang sudah mampu dalam pembelajaran Al-Qur'an akan diikutkan wisuda AlQur'an binnadhor dan bil ghoib melalui tes di lembaga dan di cabang kraksaan. Setelah santri lulus tes, santri di wisuda dengan mengundang wali murid, dan waktu wisuda santri di kasih waktu tanya jawab beserta wali murid tentang materi yang sudah diujikan, ini sebagai bukti bahwa santri yang sudah di wisuda tidak hanya hatam AlQur'an saja tapi santri juga mampu dalam menguasai materi tajwid, gharib, dan haditshadits yang sudah di pelajarinya.

Data tersebut didukung oleh hasil dokumentasi dengan adanya dokumen waktu pelaksanaan tes Al-Qur'an yang dilaksanakan di cabang Kraksaan dapat di lihat pada gambar sebagai berikut :

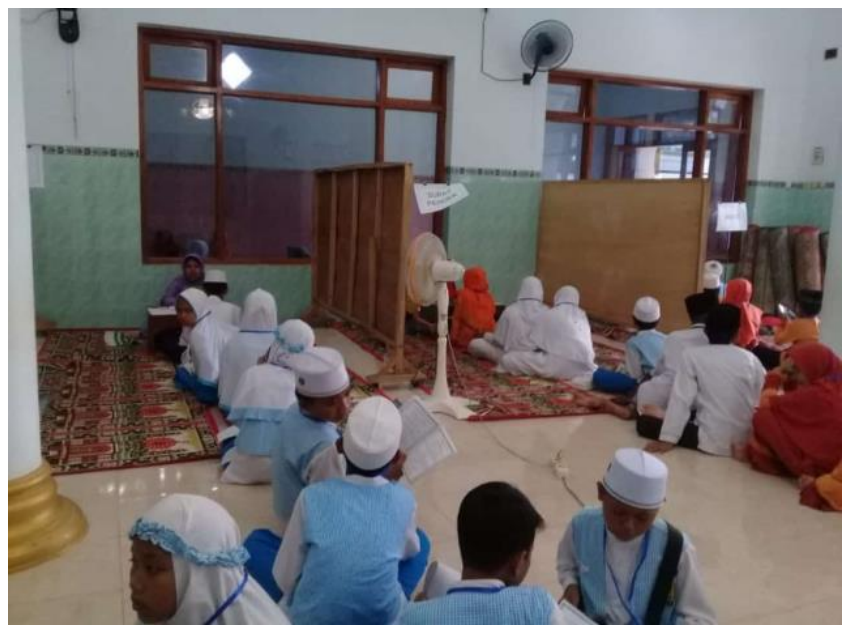

Santri yang sudah mampu dalam pembelajaran Al-Qur'an akan diikutkan wisuda di Al-Qur'an binnadhor dan bil ghoib melalui tes di lembaga dan di cabang kraksaan. Setelah santri lulus tes, santri di wisuda dengan mengundang wali murid, dan waktu wisuda santri di kasih waktu tanya jawab beserta wali murid tentang materi yang sudah diujikan, ini sebagai bukti bahwa santri yang sudah di wisuda tidak hanya hatam Al-Qur'an saja tapi santri juga mampu dalam menguasai materi tajwid, gharib, dan hadits-hadits yang sudah di pelajarinya. Pembelajaran Al-Qur'an di SD Insan Terpadu bagus karena kemampuan anak dalam melafadkan Al-Qur'an sesuai dengan makhroj dan tajwid dan para ustadz dan ustadzah juga mempunyai kemampuan yang aktif dan kreatif dalam membimbing peserta didik.

\section{Kesimpulan}

Dari paparan di atas dapat disimpulkan bahwa pendekatan Scientific Approach dalam proses pembelajaran Ilmu Tajwid di SD Insan Terpadu berjalan sangat efektif sehingga mampu meningkatkan bacaan al-Qur'an para siswa dan sangat menyenangkan. Selain itu, santri juga mampu menguasai materi tajwid, gharib, dan hadits-hadits yang sudah di pelajarinya. Pembelajaran Al-Qur'an di SD Insan Terpadu bagus karena kemampuan anak dalam melafadkan Al-Qur'an sesuai dengan makhroj dan tajwid dan para ustadz dan ustadzah juga mempunyai kemampuan yang aktif dan kreatif dalam membimbing peserta didik.

\section{Daftar Pustaka}

Abdurohim, Acep, Lim. (2003). Pedoman Ilmu Tajwid Lengkap. Bandung: CV Penerbit Diponegoro.

Annuri, Ahmad. (2007). Panduan Tahsin dan Tilawah Al-Quran \& Pembahasan Ilmu Tajwid. Bogor : Prim Publishing.

Asmani, Jamal Ma“mur. (2011). 7 Tips Aplikasi PAKEM (Pembelajaran aktif,kreatif, Efektif dan menyenangkan). Jogjakarta: DIVA Press.

Al Imam Muslim bin Al-hajjaj Al-Qusyairi AnNaisyaburi. (t.th). Terjemah Hadist Shahih Muslim. Semarang: Maktabah.

Arifin. (1991). IImu Pendidikan Islam Suatu Tinjauan Teoritis dan Praktis Berdasarkan Pendekatan Interdisipliner. Jakarta :Bumi Aksara.

Baharun, Hasan. (2017). Pengembangan Kurikulum Teori dan Praktek. Yogyakarta : Pustaka Nurja.

Bukhari, Umar. (2010). Ilmu Pendidikan Islam. Amzah : Jakarta.

Dimyati dan Mudjiono. (2015). Belajar dan Pembelajaran. Jakarta: Rineka Cipta.

Dokumentasi. (2019). Sekolah SD Insan Terpadu, pada tanggal 25 Februari 2019.

Khanifatul. (2014). Pembelajarn Inovatif. Yogyakarta: PT Ar-ruzz Media.

Musfiqon, Nurdyansyah. (2015). Pendekatan Pembelajaran Saintifik. Sidoarjo: Nizamia Learning Center. 
Observasi. (2019). Sekolah SD Insan Terpadu, pada tanggal 28 Februari 2019

Rasimin. (2012). Pembelajaran IPS Teori, Aplikasi dan Evaluasi. Salatiga: STAIN Salatiga Press.

Razaq, Hefniy. (2011). "Pendidik dalam Perspektif Al-qur'an", Jurnal Studi Keislaman dan Sosial, 1(1).

Rusman. (2013). Model-Model Pembelajaran Mengembangkan Profesioanalisme Guru. Jakarta : Rajawali Pers.

Sani, Ridwan Abdullah. (2014). Pembelajaran Saintifik untuk Implementasi Kurikulum 2013. Jakarta: PT Bumi Aksara.

Winarno Surachmad. (1980). Pengantar Interaksi Belajar Mengajar. Bandung : Tarsito.

Zulfison dan Muharram. (2003). Belajar Mudah Membaca Al-Quran dengan Metode Mandiri. Jakarta: Ciputat Press. 